Check for updates

Cite this: Chem. Sci., 2018, 9, 5837

Received 13th April 2018

Accepted 7th June 2018

DOI: $10.1039 / \mathrm{c} 8 \mathrm{sc} 01682 \mathrm{~h}$

rsc.li/chemical-science

\section{Tris(benzoimidazol)amine (L) complexes of pnictogen(III) and pnictogen(v) cations and assessment of the $\left[\mathrm{LP}^{3+} /\left[\mathrm{LPF}_{2}\right]^{3+}\right.$ redox couple $\uparrow$}

\author{
Ala'aeddeen Swidan, (D) $\star^{\mathrm{a}}$ Riccardo Suter, (D) $\star^{* \mathrm{~b}}$ Charles L. B. Macdonald (D) *a \\ and Neil Burford (iD *b
}

A series of cationic complexes involving a pnictogen(III) ( $\mathrm{Pn}=\mathrm{P}, \mathrm{As}, \mathrm{Sb})$ centre and the tetradentate ligand tris((1-ethyl-benzoimidazol-2-yl)methyl)amine (BIMEt 3 ) have been synthesized and comprehensively characterized. Oxidation of $\left[\mathrm{P}\left(\mathrm{BIMEt}_{3}\right)\right]^{3+}$ with $\mathrm{XeF}_{2}$ provides access to $\left[\mathrm{PF}_{2}\left(\mathrm{BIMEt}_{3}\right)\right]^{3+}$ representing the first structurally characterized example of a phosphorus(v) centred trication.

\section{Introduction}

Phosphorus(III) centers can undergo reversible oxidative addition of $\mathrm{N}-\mathrm{H}$ and $\mathrm{O}-\mathrm{H}$ bonds and have potential application as catalysts in organic transformations. ${ }^{1}$ This traditional Lewis basic reactivity extends to pnictogen(III) centers in general, but has been challenged by the realization of the Lewis acid "umpolung" made possible by the introduction of a cationic charge. ${ }^{2}$ A variety of pnictogen(III) based cations have been synthesized by halide abstraction from $\mathrm{PnX}_{3}$ derivatives in the presence of various ligands and weakly coordinating anions. ${ }^{3}$ The cationic charge of such complexes not only lowers the energy of the pnictogen based LUMO but also lowers the energy of the HOMO, so that oxidation is impeded. Consequently, examples of redox couples of the type $[\mathrm{Pn}(\mathrm{III}) \mathrm{L}]^{3+} /\left[\mathrm{Pn}(\mathrm{v}) \mathrm{R}_{2} \mathrm{~L}\right]^{3+}$ have not yet been reported. The fluorophilicity of ligand stabilized phosphenium cations ${ }^{4}$ and dications ${ }^{5}$ is well established and has led to the discovery of effective catalysts for hydrofluorination reactions. ${ }^{6}$ The Lewis acidity of $[\mathrm{PRL}]^{2+}$ with $\mathrm{L}=$ terpyridine renders it an active catalyst for dehydrofluorination of fluoroalkanes, and suggests it has a substantial fluoride ion affinity. ${ }^{7}$

We have recently shown that the multidentate tris(benzoimidazol)amine ligand $\left(\mathrm{BIMEt}_{3}\right)$ encapsulates a germanium dication that is readily oxidized to $\left[\mathrm{GeF}_{2} \mathrm{BIMEt}_{3}\right][\mathrm{OTf}]_{2},{ }^{8}$ and we have now exploited the versatility of this ligand to synthesise derivatives of $\left[\mathrm{Pn}\left(\mathrm{BIMEt}_{3}\right)\right][\mathrm{OTf}]_{3}$ for $\mathrm{Pn}=\mathrm{P}$, As and $\mathrm{Sb}$. As an

\footnotetext{
${ }^{a}$ Department of Chemistry and Biochemistry, University of Windsor, Windsor, Ontario N9B 3P4, Canada. E-mail: cmacd@uwindsor.ca

${ }^{b}$ Department of Chemistry, University of Victoria, Victoria, British Columbia V8W 3V6, Canada.E-mail: nburford@uvic.ca; risuter@uvic.ca

$\dagger$ Electronic supplementary information (ESI) available. CCDC 1578584-1578587, 1581022, 1581023 and 1819912. For ESI and crystallographic data in CIF or other electronic format see DOI: $10.1039 / \mathrm{c} 8 \mathrm{sc} 01682 \mathrm{~h}$

\$ These authors contributed equally to this work.
}

analogue of the Verkade superbases $[\mathrm{P}(\mathrm{PRZ})],{ }^{9}\left[\mathrm{P}\left(\mathrm{BIMEt}_{3}\right)\right]^{3+}$ adopts a proazaphosphatrane type cage structure. Oxidation of $\left[\mathrm{P}\left(\mathrm{BIMEt}_{3}\right)\right][\mathrm{OTf}]_{3}$ by $\mathrm{XeF}_{2}$ gives $\left[\mathrm{PF}_{2}\left(\mathrm{BIMEt}_{3}\right)\right][\mathrm{OTf}]_{3}$, containing a rare example of a cationic complex of the high oxidation state $\operatorname{Pn}(\mathrm{v})$ center. $^{10}$ Previous examples include derivatives of $\left[\mathrm{PnPh}_{3} \mathrm{~L}_{x}\right][\mathrm{OTf}]_{2}\left(\mathrm{~L}=\right.$ pyridine N-oxide and $\left.\mathrm{Pn}=\mathrm{As},{ }^{11} \mathrm{Sb}, \mathrm{Bi}^{12}\right)$ and $\left[\mathrm{SbPh}_{2} \mathrm{~L}_{x}\right][\mathrm{OTf}]_{3}\left(\mathrm{~L}=\right.$ pyridine $\mathrm{N}$-oxide $\left.{ }^{\mathbf{1 3}}\right)$.

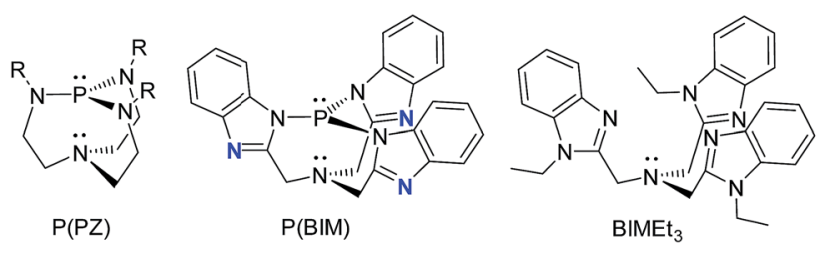

\section{Results}

The reaction of $\mathrm{BIMH}_{3}$ and $\mathrm{PCl}_{3}$ in the presence of a slight excess of $\mathrm{NaH}$ in $\mathrm{THF}$ at room temperature gives $\mathrm{P}(\mathrm{BIM}){ }^{\mathbf{1 4}}$ Quantitative formation of $\mathrm{P}(\mathrm{BIM})$ is evidenced by a single peak in the ${ }^{31} \mathrm{P}$ NMR spectrum $\left({ }^{31} \mathrm{P} \delta=44.7 \mathrm{ppm}\right)$. Crystals of $\mathrm{P}(\mathrm{BIM})$ were obtained by slow evaporation of the solvent from a DCM/ MeCN solution. In the solid-state structure (Fig. 1a), two enantiomers are present in the unit cell, with the benzoimidazole groups arranged either in an $S$ or $R$ configuration. The geometry at $\mathrm{N} 1$ is essentially planar (353.77 and $355.85^{\circ}$, respectively) and features a pre-ordered $\mathrm{N} 1 \cdots \mathrm{P}$ bond with an average distance of $2.925 \AA$. The P-N3 bonds (1.721 $\mathrm{A})$ are significantly longer than those observed in $\mathrm{P}(\mathrm{PZ})$ (e.g. $1.694 \AA$ for $\mathrm{N}\left(\mathrm{CH}_{2}-\mathrm{CH}_{2}-\mathrm{NR}\right)_{3} \mathrm{P}$ with $\mathrm{R}=\mathrm{CH}(\mathrm{Me}) \mathrm{Ph}){ }^{15}$ The nucleophilic behaviour of $\mathrm{P}(\mathrm{BIM})$ was explored through reactions involving a variety of stoichiometric ratios of methyltriflate. In each case the ${ }^{31} \mathrm{P}-\mathrm{NMR}$ spectrum of the reaction mixture indicated the formation of several products that we speculate to result from simultaneous methylation of the nitrogen and phosphorus atoms. We have modelled the 
energetic profile of the reactions using DFT calculations at the PBEPBE/6-311+G(d,p) level of theory. ${ }^{\mathbf{1 6}}$

Geometry optimizations for each complex suggest that methylation is favoured at the imino nitrogen atoms (Table 1). In the gas phase each methylation of an imino centre is exergonic. Similar results were obtained with $\mathrm{MeCN}$ as a solvent model but an energetic minimum was not evident for $\left[\mathrm{PMe}\left(\mathrm{BIMMe}_{3}\right)\right]^{4+}$ (Table 1 and ESI $\dagger$ ), and consistently, complicated reaction mixtures are observed for MeOTf and $\mathrm{P}(\mathrm{BIM})$. Nevertheless, addition of excess MeOTf resulted in a colourless precipitate (insoluble in common organic solvents) which suggests the potential formation of $\left[\mathrm{PMe}\left(\mathrm{BIMMe}_{3}\right)\right]^{4+}$. We have modelled the bonding in the potentially stable tricationic complex $\left[\mathrm{BIMMe}_{3} \mathrm{P}\right]^{3+}$ (at the PBEPBE/6-311+G(d,p) level of theory). NBO analysis on the optimized structure reveals a natural charge of +1.5 at phosphorus, and +0.5 on each benzoimidazole group, consistent with relatively strong $\mathrm{P}-\mathrm{N}$ bonds (Wiberg bond index of 0.73 ).

Based on the modelled stability of $\left[\mathrm{P}\left(\mathrm{BIMMe}_{3}\right)\right]^{3+}$, we examined the reaction of $\mathrm{BIMEt}_{3}$ (ref. 17) with "P(OTf) $)_{3}$ " by mixing $\mathrm{PCl}_{3}$ and AgOTf acetonitrile in the presence of $\mathrm{BIMEt}_{3}$ (Scheme 1a). A singlet at $\delta=56.1 \mathrm{ppm}$ in the ${ }^{31} \mathrm{P}$ NMR spectrum indicates the quantitative formation of $\left[\mathrm{P}\left(\mathrm{BIMEt}_{3}\right)\right][\mathrm{OTf}]_{3}$ which has been separated from the $\mathrm{AgCl}$ by filtration, and crystallized by layering the reaction mixture with diethyl ether. The analogous reactions of $\mathrm{AsCl}_{3}$ or $\mathrm{SbCl}_{3}$ provided $\left[\mathrm{As}\left(\mathrm{BIMEt}_{3}\right)\right][\mathrm{OTf}]_{3}$ and $\left[\mathrm{Sb}\left(\mathrm{BIMEt}_{3}\right)\right][\mathrm{OTf}]_{3}$, respectively. In contrast, reaction of $\mathrm{AsCl}_{3}$ with BIMEt ${ }_{3}$ and excess TMSOTf formed $\left[\mathrm{AsCl}\left(\mathrm{BIMEt}_{3}\right)\right][\mathrm{OTf}]_{2}$ as a primary product (Scheme 1b), which has been isolated in small quantities. The antimony fluoride derivative
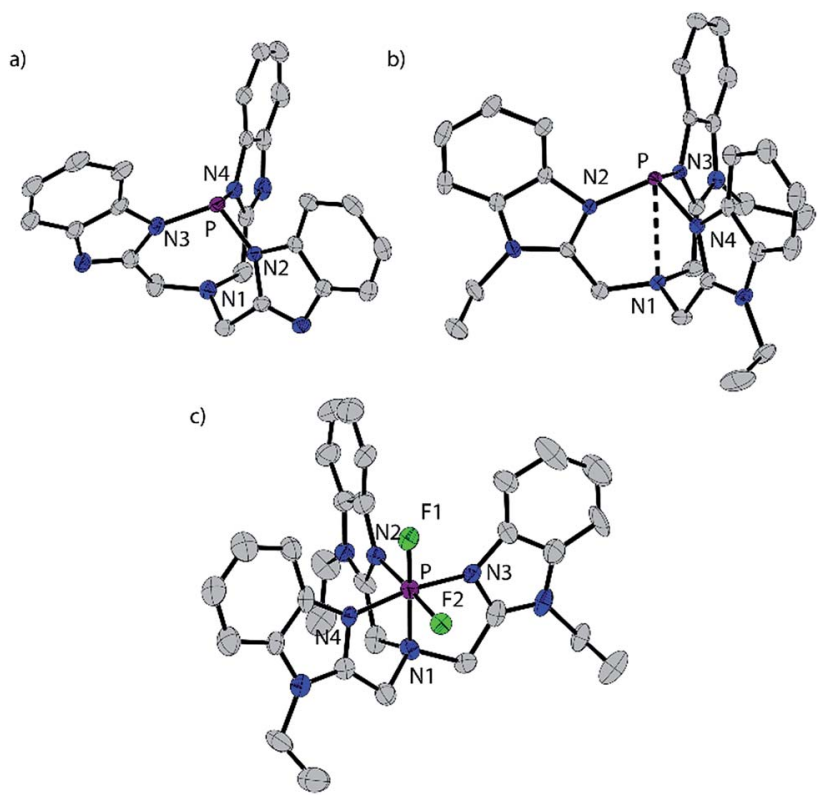

Fig. 1 Solid state structures of one of two independent molecules of $\mathrm{P}(\mathrm{BIM})(\mathrm{a})$, the cation in $\left[\mathrm{P}\left(\mathrm{BIMEt}_{3}\right)\right][\mathrm{OTf}]_{3} \cdot(\mathrm{MeCN})_{2}(\mathrm{~b})$, and cation in $\left[\mathrm{PF}_{2}\left(\mathrm{BIMEt}_{3}\right)\right][\mathrm{OTf}]_{3} \cdot \mathrm{MeCN}$ (c). Thermal ellipsoids are shown at a $50 \%$ probability level. Hydrogen atoms, solvent molecules and triflate anions are omitted for clarity. Inter-atomic distances and angles are summarized in Table 2.
Table 1 Gibbs free energies of optimized gas phase structures for the stepwise methylation of $[P(B \mid M)]$ at the PBEPBE/6-311+G(d,p) level of theory. $\mathrm{N}$-methylation in blue and $P$-methylation in red
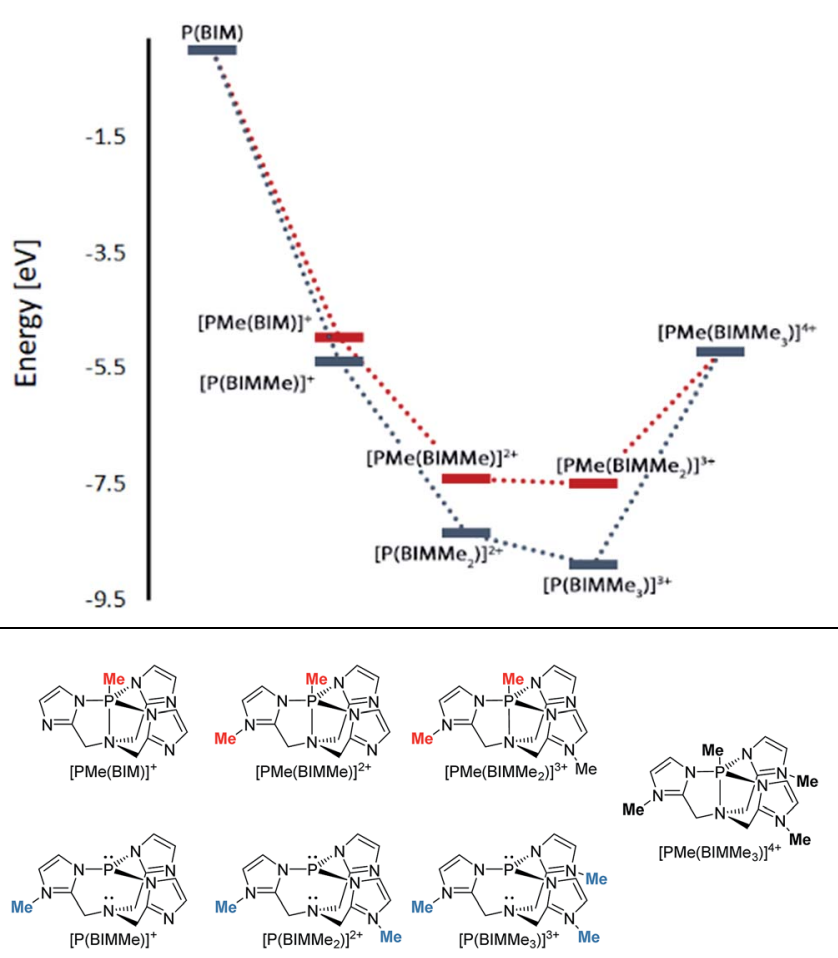

\begin{tabular}{|c|c|c|c|}
\hline$N$-Methylation & $\mathrm{eV}$ & $P$-Methylation & $\mathrm{eV}$ \\
\hline $\mathrm{P}(\mathrm{BIM})+4 \mathrm{Me}^{+}$ & 0 & $\mathrm{P}(\mathrm{BIM})+4 \mathrm{Me}^{+}$ & 0 \\
\hline$[\mathrm{P}(\mathrm{BIMMe})]^{+}+3 \mathrm{Me}^{+}$ & -5.38 & {$[\mathrm{PMe}(\mathrm{BIM})]^{+}+3 \mathrm{Me}^{+}$} & -4.96 \\
\hline$\left[\mathrm{P}\left(\mathrm{BIMMe}_{2}\right)\right]^{2+}+2 \mathrm{Me}^{+}$ & -8.34 & {$[\mathrm{PMe}(\mathrm{BIMMe})]^{2+}+2 \mathrm{Me}^{+}$} & -7.40 \\
\hline$\left[\mathrm{P}\left(\mathrm{BIMMe}_{3}\right)\right]^{3+}+1 \mathrm{Me}^{+}$ & -8.90 & {$\left[\mathrm{PMe}\left(\mathrm{BIMMe}_{2}\right)\right]^{3+}+1 \mathrm{Me}^{+}$} & -7.49 \\
\hline$\left[\mathrm{PMe}\left(\mathrm{BIMMe}_{3}\right)\right]^{4+}$ & -5.21 & {$\left[\mathrm{PMe}\left(\mathrm{BIMMe}_{3}\right)\right]^{4+}$} & -5.21 \\
\hline
\end{tabular}

$\left[\mathrm{SbF}\left(\mathrm{BIMEt}_{3}\right)\right][\mathrm{OTf}]_{2}$ is formed quantitatively in the reaction of $\mathrm{SbF}_{3}$ with BIMEt ${ }_{3}$ and two equivalents of TMSOTf (Scheme 1c). The derivatives of $\left[\mathrm{MX}\left(\mathrm{BIMEt}_{3}\right)\right][\mathrm{OTf}]_{2}$ exhibit one set of signals for the benzoimidazole groups in the ${ }^{1} \mathrm{H}-\mathrm{NMR}$ spectrum, consistent with the triflate being labile in solution, as observed for analogous germanium complexes. ${ }^{8}$

$\left[\mathrm{P}\left(\mathrm{BIMEt}_{3}\right)\right][\mathrm{OTf}]_{3} \cdot(\mathrm{MeCN})_{2}$ crystallizes in the space group $P \overline{1}$ (see Fig. 1b). The three triflate anions are remote from the phosphorus centre (3.58-3.92 $\AA$ ). The unique apex nitrogen atom $\left({ }^{\circ} \Sigma_{\mathrm{N} 1}=350.5\right)$ is significantly bent out of plane towards the phosphorus centre consistent with a cross-ring bonding interaction. Nevertheless, $\mathrm{N} 1 \cdots \mathrm{P}(2.866(2) \AA)$ is only slightly shorter than those in $\mathrm{P}(\mathrm{BIM})(2.912(2)$ and $2.938(2) \AA)$. In the solid state $\left[\mathrm{As}\left(\mathrm{BIMEt}_{3}\right)\right][\mathrm{OTf}]_{3}$ and $\left[\mathrm{Sb}\left(\mathrm{BIMEt}_{3}\right)\right][\mathrm{OTf}]_{3}$ (Fig. 2c and d) exhibit a significantly different geometry around the pnictogen centre. The polygon described by the ligands is best described as a pentagonal bipyramid with three nitrogen atoms (N1, N2 and N3), one triflate oxygen atom and the lone pair in the plane. A second triflate oxygen atom and one nitrogen (N4) atom occupy the axial positions. This geometry enables significantly shorter Pn-N1 bond (As-N1 2.104(4) and Sb-N1 2.389(2) 
a) $\mathrm{BIMEt}_{3}+\mathrm{PnX}_{3} \frac{3 \mathrm{AgOTf}}{-3 \mathrm{AgCl}}\left[\mathrm{Pn}\left(\mathrm{BIMEt}_{3}\right)\right][\mathrm{OTf}]_{3}$

b) $\mathrm{BIMEt}_{3}+\mathrm{PnX}_{3} \underset{-2 \mathrm{TMSCl}}{\stackrel{2 \mathrm{TMSOTf}}{\longrightarrow}}\left[\mathrm{PnX}\left(\mathrm{BIMEt}_{3}\right)\right][\mathrm{OTf}]_{2}$

$\mathrm{Pn}=\mathrm{As} ; \mathrm{X}=\mathrm{Cl}$

$\mathrm{Pn}=\mathrm{Sb} ; \mathrm{X}=\mathrm{F}$

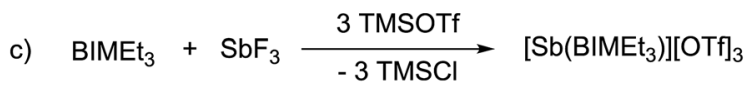

d) $\left[\mathrm{P}\left(\mathrm{BIMEt}_{3}\right)\right][\mathrm{OTf}]_{3} \frac{\mathrm{XeF}_{2}}{-\mathrm{Xe}}\left[\mathrm{PF}_{2}\left(\mathrm{BIMEt}_{3}\right)\right][\mathrm{OTf}]_{3}$

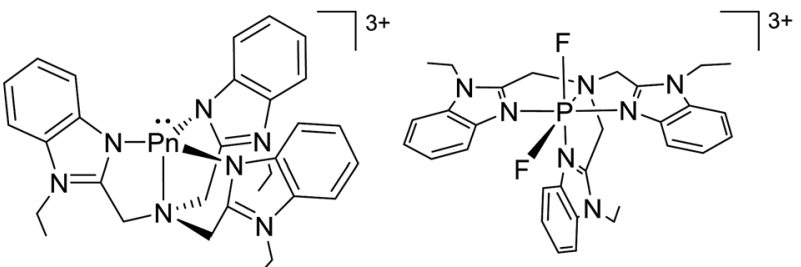

Scheme 1 Synthetic procedure for derivatives of $\left[\mathrm{PnX}\left(\mathrm{BIMEt}_{3}\right)\right][\mathrm{OTf}]_{2}$ $\left[\mathrm{Pn}\left(\mathrm{BIMEt}_{3}\right)\right][\mathrm{OTf}]_{3}$ and $\left[\mathrm{PF}_{2}\left(\mathrm{BIMEt}_{3}\right)\right][\mathrm{OTf}]_{3}$.
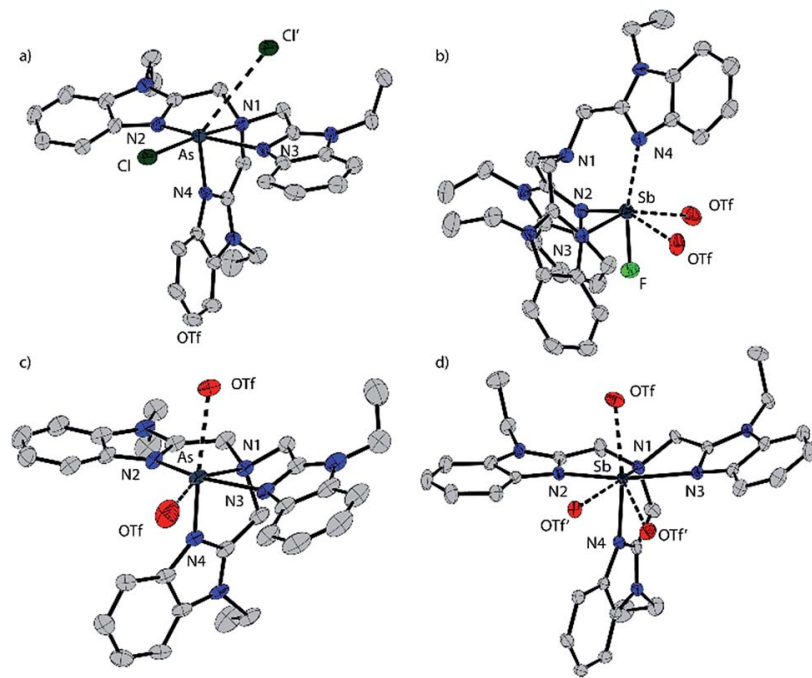

Fig. 2 Solid state structure of the cations in $\left[\mathrm{AsCl}\left(\mathrm{BIMEt}_{3}\right)\right][\mathrm{OTf}]_{2}(\mathrm{a})$, $\left[\mathrm{SbF}\left(\mathrm{BIMEt}_{3}\right)\right][\mathrm{OTf}]_{2}(\mathrm{~b}),\left[\mathrm{As}\left(\mathrm{BIMEt}_{3}\right)\right][\mathrm{OTf}]_{3}$ (c), and $\left[\mathrm{Sb}\left(\mathrm{BIMEt}_{3}\right)\right][\mathrm{OTf}]_{3}$ (d). Thermal ellipsoids are shown at a 50\% probability level. Oxygen atoms of the triflate anions that interact with the pnictogen centres are shown, but the other atoms of the anions are omitted for clarity as well as the hydrogen atoms and solvent molecules. Interatomic distances and angles are summarized in Table 3.

and 2.370(2) $\AA$, respectively) compared to that in [P(BIMEt $\left.\left.{ }_{3}\right)\right]$ $[\mathrm{OTf}]_{3}(\mathrm{P}-\mathrm{N} 12.879 \AA)$. Two of the three triflate anions have a weak interaction with the pnictogen centre (Table 3). The mono-halide derivatives $\left[\mathrm{SbF}\left(\mathrm{BIMEt}_{3}\right)\right][\mathrm{OTf}]_{2}$ and $\left[\mathrm{AsCl}\left(\mathrm{BIMEt}_{3}\right)\right]$ $[\mathrm{OTf}]_{2}$ crystallise as dimeric structures. The antimony fluoride is linked by two triflate anions and the arsenic chloride is linked
Table 2 Selected bond distances in $\AA$, angles in ${ }^{\circ}$ and ${ }^{31} \mathrm{P} N M R$ chemical shifts in ppm for $\mathrm{P}(\mathrm{BIM}),\left[\mathrm{P}\left(\mathrm{BIMEt}_{3}\right)\right][\mathrm{OTf}]_{3}$ and $\left[\mathrm{PF}_{2}\left(\mathrm{BIMEt}_{3}\right)\right]$ $[\mathrm{OTf}]_{3}$

\begin{tabular}{llll}
\hline & $\mathrm{P}(\mathrm{BIM})$ & {$\left[\mathrm{P}\left(\mathrm{BIMEt}_{3}\right)\right]^{3+}$} & {$\left[\mathrm{PF}_{2}\left(\mathrm{BIMEt}_{3}\right)\right]^{3+}$} \\
\hline $\mathrm{P}-\mathrm{N} 2$ & $1.7281(11)$ & $1.7279(16)$ & $1.791(13)$ \\
& $1.7159(11)$ & $1.7352(16)$ & $1.798(13)$ \\
& $1.7201(11)$ & $1.7364(16)$ & $1.773(13)$ \\
& $1.7246(12)$ & & \\
& $1.7137(11)$ & & \\
& $1.7242(12)$ & & $1.893(13)$ \\
$\mathrm{P}-\mathrm{N} 1$ & $2.912(2)$ & $2.866(2)$ & - \\
& $2.938(2)$ & & \\
$\mathrm{P}-\mathrm{OTf}$ & - & $3.591(2)$ & $1.604(9)$ \\
& & $3.922(2)$ & $-127.8(\mathrm{dd})$ \\
$\mathrm{P}-\mathrm{F}$ & - & - & - \\
& & & $3284(2)$ \\
${ }^{31} \mathrm{P} \delta$ & $44.7(\mathrm{~s})$ & $56.1(\mathrm{~s})$ & \\
${ }^{\circ} \Sigma_{\mathrm{P}}$ & 319.48 & 320.2 & \\
& 317.75 & & \\
${ }^{\circ} \Sigma_{\mathrm{N} 1}$ & 353.77 & 350.5 & \\
& 355.85 & & \\
\hline
\end{tabular}

by chlorine substituents (As-Cl 2.3342(7) and 3.913(2) $\AA$ ). The antimony centre adopts a tetragonal pyramidal geometry with two oxygen atoms from the triflate anions (Sb-OTf 2.551(2) and 2.793(2) $\AA$ ) and two nitrogen atoms (Sb-N 2.214(2) and 2.165(2) $\AA)$ with the antimony centre $0.486 \AA$ above this plane.

Equimolar mixtures of $\mathrm{PCl}_{5}$ and $\mathrm{BIMEt}_{3}$ with three equivalents of AgOTf give a mixture of products as evidenced by the ${ }^{31} \mathrm{P}$ NMR spectrum of the reaction mixture. Isolation of [P(BIMEt $\left.\left.\mathrm{BL}_{3}\right)\right]$ $[\mathrm{OTf}]_{3}$ from this mixture implicates formation of $\left[\mathrm{PCl}_{2}\left(\mathrm{BIMEt}_{3}\right)\right]$ $[\mathrm{OTf}]_{3}$, which is subsequently reduced. In this context, we have studied the oxidation of $\left[\mathrm{P}\left(\mathrm{BIMEt}_{3}\right)\right][\mathrm{OTf}]_{3}$ with the expectation to form cationic compounds analogous to $\left[\mathrm{PPh}_{3} \mathrm{I}\right]\left[\mathrm{I}_{3}\right]^{18}$ or $\left[\mathrm{Ph}_{3} \mathrm{P}-\right.$ $\mathrm{I}-\mathrm{I}]^{19}$ However, reaction of addition of $\left[\mathrm{P}\left(\mathrm{BIMEt}_{3}\right)\right][\mathrm{OTf}]_{3}$ with a large excess of $\mathrm{I}_{2}$ caused only a small chemical shift in the ${ }^{31} \mathrm{P}$ NMR spectrum and a product could not be isolated. Nevertheless, Stephan's approach for oxidation of phosphenium cations ${ }^{4}$ was applied using equimolar mixtures of $\left[\mathrm{P}\left(\mathrm{BIMEt}_{3}\right)\right][\mathrm{OTf}]_{3}$ and $\mathrm{XeF}_{2}$ (Scheme 1d) in acetonitrile to yield a mixture of products with a prominent doublet of doublets resonance in the ${ }^{31} \mathrm{P}-\mathrm{NMR}$ spectrum $\left({ }^{31} \mathrm{P} \delta=-127.8 \mathrm{ppm} ;{ }^{1} J_{\mathrm{PF}}=899.3\right.$ and $\left.849.7 \mathrm{~Hz}\right)$ and consistently, two doublet of doublet resonances in the ${ }^{19} \mathrm{~F} \mathrm{NMR}$ spectrum $\left(\delta=-65.5\right.$ and $\left.-33.9 \mathrm{ppm} ;{ }^{2} J_{\mathrm{FF}}=52.0 \mathrm{~Hz}\right)$. Attempts to scale up the reaction yielded several different fluorinated phosphorus species. Rapid crystallization from a saturated acetonitrile solution at $-35^{\circ} \mathrm{C}$ layered with diethyl ether yielded small amounts of fragile crystals, that have been characterized as $\left[\mathrm{PF}_{2}\left(\mathrm{BIMEt}_{3}\right)\right][\mathrm{OTf}]_{3}$. Consistent with the solution NMR spectra (Fig. 3), the solid state structure reveals, inequivalent fluorine substituents at phosphorus (Fig. 1c) and two different benzoimidazole environments.

The N1-P distance (1.893(13) $\AA$ ) is significantly shorter than that in $\left[\mathrm{P}\left(\mathrm{BIMEt}_{3}\right)\right][\mathrm{OTf}]_{3}$. The P-F1 bond trans to the tertiary amine is longer $[1.577(9) \AA]$ than P-F2 [1.604(9) $\AA$ ]. Consequently, the pseudo $C_{3 v^{-}}$geometry of the cation in $\left[\mathrm{P}\left(\mathrm{BIMEt}_{3}\right)\right]$ 
Table 3 Selected bond distances in $\AA$ for $\left.\left[\mathrm{AsCl}\left(\mathrm{BIMEt}_{3}\right)\right][\mathrm{OTf}]_{2}\left[\mathrm{SbF}\left(\mathrm{BIMEt}_{3}\right)\right][\mathrm{OTf}]_{2}\left[\mathrm{As}_{(\mathrm{BIMEt}}\right)\right][\mathrm{OTf}]_{3}$ and $\left[\mathrm{Sb}\left(\mathrm{BIMEt}_{3}\right)\right][\mathrm{OTf}]_{3}$

\begin{tabular}{|c|c|c|c|c|c|}
\hline & {$\left[\mathrm{AsCl}\left(\mathrm{BIMEt}_{3}\right)\right]^{3+}$} & {$\left[\mathrm{As}\left(\mathrm{BIMEt}_{3}\right)\right]^{3+}$} & {$\left[\mathrm{SbF}\left(\mathrm{BIMEt}_{3}\right)\right]^{2+}$} & {$\left[\mathrm{Sb}\left(\mathrm{BIMEt}_{3}\right)\right]^{3+}$} & \\
\hline \multirow[t]{2}{*}{$\mathrm{Pn}-\mathrm{N} 2$} & $1.964(2)$ & $1.918(4)$ & $2.214(2)$ & $2.193(2)$ & $2.168(2)$ \\
\hline & $2.078(2)$ & $2.085(4)$ & $2.165(3)$ & $2.233(2)$ & $2.246(2)$ \\
\hline Pn-N1 & $2.268(2)$ & $2.104(4)$ & $2.635(3)$ & $2.389(2)$ & $2.370(2)$ \\
\hline \multirow[t]{2}{*}{ Pn-OTf } & - & $2.646(4)$ & $2.551(2)$ & $2.421(2)$ & $2.485(2)$ \\
\hline & & $2.796(4)$ & $2.793(2)$ & $3.181(2)$ & $3.171(2)$ \\
\hline $\mathrm{Pn}-\mathrm{X}$ & $2.3342(7) 3.913(2) \mathrm{X}=\mathrm{Cl}$ & & $1.9344(19) \mathrm{X}=\mathrm{F}$ & & \\
\hline
\end{tabular}

${ }^{31} \mathrm{P}-\mathrm{NMR}$ spectrum of $\left[\left(\mathrm{BIMEt}_{3}\right) \mathrm{PF}_{2}\right]^{3+}$
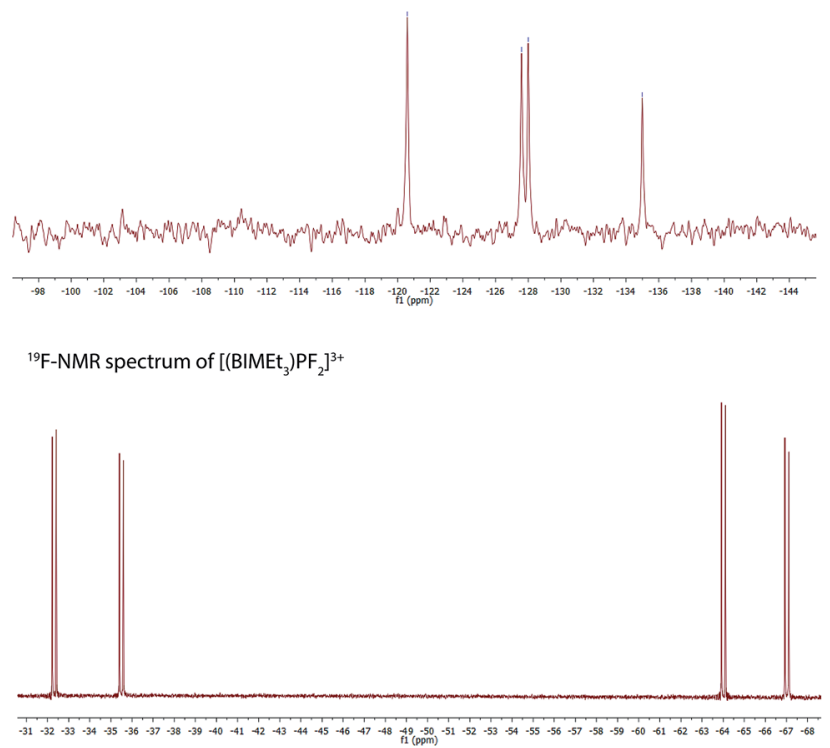

Fig. 3 NMR spectra for $\left[\mathrm{PF}_{2}\left(\mathrm{BIMEt}_{3}\right)\right][\mathrm{OTf}]_{3}$ in $\mathrm{CD}_{3} \mathrm{CN}$.

$[\mathrm{OTf}]_{3}$ adjusts to $C_{\mathrm{s}}$ symmetry in the octahedral frame in $\left[\mathrm{PF}_{2}\left(\mathrm{BIMEt}_{3}\right)\right][\mathrm{OTf}]_{3}$. Moreover, $\mathrm{P}-\mathrm{N} 1$ in $\left[\mathrm{PF}_{2}\left(\mathrm{BIMEt}_{3}\right)\right][\mathrm{OTf}]_{3}$ is shorter than that in $\left[\mathrm{P}\left(\mathrm{BIMEt}_{3}\right)\right][\mathrm{OTf}]_{3}$ and the other $\mathrm{P}-\mathrm{N}$ bonds are longer (Table 2). This substantive change in geometry is also evidenced by ${ }^{31} \mathrm{P}$ NMR spectroscopy $\left(\left[\mathrm{P}\left(\mathrm{BIMEt}_{3}\right)\right]^{3+} \delta=-127.8\right.$ ppm) with a chemical shift difference of $184 \mathrm{ppm}$ upon oxidation. There are no close interactions of the phosphorus centre with any of the triflate anions, so that the cation in $\left[\mathrm{PF}_{2}\left(\mathrm{BIMEt}_{3}\right)\right][\mathrm{OTf}]_{3}$ represents the first fully characterized tricationic $\mathrm{P}(\mathrm{v})^{3+}$ species.

\section{Conclusions}

We have presented a versatile and facile synthetic approach to a number of pnictogen(III) cations in the BIMEt $_{3}$ ligand scaffold. The phosphorus derivative $\left[\mathrm{P}\left(\mathrm{BIMEt}_{3}\right)\right][\mathrm{OTf}]_{3}$ can be readily oxidized to form the first tricationic phosphorus(v) complex, $\left[\mathrm{LP}^{\mathrm{V}} \mathrm{F}_{2}\right]^{3+}$. A fundamental study for general use of such pnictogen salts in Lewis acid catalysis, small molecule activation or as catalytic fluorinating agents is ongoing.

\section{Conflicts of interest}

The authors declare no conflict of interest.

\section{Acknowledgements}

The work was supported by the University of Victoria, University of Windsor and the Natural Sciences and Engineering Research Council of Canada (NSERC) 2016-05260 (NB) and 249809-2013 (CLBM). This research was enabled in part by support provided by WestGrid and Compute Canada (https:// www.computecanada.ca). Robert Mac Donald from the University of Alberta is thanked for his assistance regarding X-ray crystallography and Hannah Sinclair from University of Victoria for preliminary synthetic work.

\section{Notes and references}

1 (a) A. J. Arduengo, C. A. Stewart, F. Davidson, D. A. Dixon, J. Y. Becker, S. A. Culley and M. B. Mizen, J. Am. Chem. Soc., 1987, 109, 627-647; (b) W. Zhao, S. M. McCarthy, T. Y. Lai, H. P. Yennawar and A. T. Radosevich, J. Am. Chem. Soc., 2014, 136, 17634-17644; (c) D. Martin, M. Soleilhavoup and G. Bertrand, Chem. Sci., 2011, 2, 389399; (d) S. M. McCarthy, Y.-C. Lin, D. Devarajan, J. W. Chang, H. P. Yennawar, R. M. Rioux, D. H. Ess and A. T. Radosevich, J. Am. Chem. Soc., 2014, 136, 4640-4650; (e) N. L. Dunn, M. Ha and A. T. Radosevich, J. Am. Chem. Soc., 2012, 134, 11330-11333; (f) J. Cui, Y. Li, R. Ganguly, A. Inthirarajah, H. Hirao and R. Kinjo, J. Am. Chem. Soc., 2014, 136, 16764-16767; (g) T. P. Robinson, D. M. De Rosa, S. Aldridge and J. M. Goicoechea, Angew. Chem., Int. Ed., 2015, 54, 13758-13763.

2 (a) S. S. Chitnis, A. P. M. Robertson, N. Burford, B. O. Patrick, R. McDonald and M. J. Ferguson, Chem. Sci., 2015, 6, 65456555; (b) S. S. Chitnis, K. A. Vos, N. Burford, R. McDonald and M. J. Ferguson, Chem. Commun., 2016, 52, 685-688; (c) F. D. Henne, A. T. Dickschat, F. Hennersdorf, K. O. Feldmann and J. J. Weigand, Inorg. Chem., 2015, 54, 6849-6861; (d) J. Petuskova, M. Patil, S. Holle, C. W. Lehmann, W. Thiel and M. Alcarazo, J. Am. Chem. Soc., 2011, 133, 20758-20760; (e) J. Carreras, M. Patil, W. Thiel and M. Alcarazo, J. Am. Chem. Soc., 2012, 134, 16753-16758; (f) J. J. Weigand, K.-O. Feldmann, 
A. K. C. Echterhoff, A. W. Ehlers and K. Lammertsma, Angew. Chem., Int. Ed., 2010, 49, 6178-6181.

3 (a) T. A. Engesser, M. R. Lichtenthaler, M. Schleep and I. Krossing, Chem. Soc. Rev., 2016, 45, 789-899; (b) A. P. M. Robertson, P. A. Gray and N. Burford, Angew. Chem., Int. Ed., 2014, 53, 6050-6069; (c) H. Sinclair, R. Suter, N. Burford, R. McDonald and M. J. Ferguson, Can. J. Chem., 2018, 1-5; (d) R. Suter, P. A. Gray, N. Burford and R. McDonald, Chem.-Eur. J., 2018, 24, 4718-4723.

4 (a) M. Mehta, M. H. Holthausen, I. Mallov, M. Pérez, Z.-W. Qu, S. Grimme and D. W. Stephan, Angew. Chem., Int. Ed., 2015, 54, 8250-8254; (b) M. H. Holthausen, M. Mehta and D. W. Stephan, Angew. Chem., Int. Ed., 2014, 53, 65386541.

5 Á. Kozma, J. Rust and M. Alcarazo, Chem.-Eur. J., 2015, 21, 10829-10834.

6 (a) C. B. Caputo, L. J. Hounjet, R. Dobrovetsky and D. W. Stephan, Science, 2013, 341, 1374-1377; (b) J. M. Bayne and D. W. Stephan, Chem. Soc. Rev., 2016, 45, 765-774.

7 S. Chitnis, F. Krischer and D. W. Stephan, Chem.-Eur. J., 2018, 24, 6543.

8 R. Suter, A. Swidan, C. L. B. Macdonald and N. Burford, Chem. Commun., 2018, 54, 4140-4143.

9 (a) H. Schmidt, C. Lensink, S. K. Xi and J. G. Verkade, Z. Anorg. Allg. Chem., 1989, 578, 75-80; (b) J. Tang, J. Dopke and J. G. Verkade, J. Am. Chem. Soc., 1993, 115, 5015-5020; (c) J. S. Tang and J. G. Verkade, J. Am. Chem. Soc., 1993, 115, 1660-1664; (d) P. B. Kisanga and J. G. Verkade, Tetrahedron, 2001, 57, 467-475; (e) S. Mummadi,
D. Kenefake, R. Diaz, D. K. Unruh and C. Krempner, Inorg. Chem., 2017, 56, 10748-10759.

10 P. A. Gray and N. Burford, Coord. Chem. Rev., 2016, 324, 1-16. 11 M. Donath, M. Bodensteiner and J. J. Weigand, Chem.-Eur. J., 2014, 20, 17306-17310.

12 A. P. M. Robertson, N. Burford, R. McDonald and M. J. Ferguson, Angew. Chem., Int. Ed., 2014, 53, 3480-3483.

13 C. Frazee, N. Burford, R. McDonald, M. J. Ferguson, A. Decken and B. O. Patrick, Chem.-Eur. J., 2018, 24, 40114013.

14 (a) S.-R. Zhang, D.-Y. Du, J.-S. Qin, S.-J. Bao, S.-L. Li, W.-W. He, Y.-Q. Lan, P. Shen and Z.-M. Su, Chem.-Eur. J., 2014, 20, 3589-3594; (b) X. Liu, Y. Bai and J. G. Verkade, J. Organomet. Chem., 1999, 582, 16-24; (c) P. L. Shutov, S. S. Karlov, K. Harms, D. A. Tyurin, A. V. Churakov, J. Lorberth and G. S. Zaitseva, Inorg. Chem., 2002, 41, 6147-6152.

15 X. Liu, P. Ilankumaran, I. A. Guzei and J. G. Verkade, J. Org. Chem., 2000, 65, 701-706.

16 M. J. Frisch, et al., Gaussian 16., Revision. A.03., Gaussian, Inc., Wallingford CT, 2016.

17 D. G. Lonnon, D. C. Craig and S. B. Colbran, Dalton Trans., 2006, 3785-3797.

18 F. A. Cotton and P. A. Kibala, J. Am. Chem. Soc., 1987, 109, 3308-3312.

19 (a) S. M. Godfrey, D. G. Kelly, C. A. McAuliffe, A. G. Mackie, R. G. Pritchard and S. M. Watson, J. Chem. Soc., Chem. Commun., 1991, 1163-1164; (b) T. P. Robinson, D. De Rosa, S. Aldridge and J. M. Goicoechea, Chemistry, 2017, 23, 15455-15465. 